\title{
SACRED OR PROFANE? TOURISM ETHICS OF MAJOR RELIGIOUS SITES IN EUROPE AND JAPAN
}

\author{
LORENZ POGGENDORF \\ Department of International Tourism Studies, Toyo University, Japan
}

\begin{abstract}
Europe is the number one tourism destination in the world and, in Japan, inbound tourism is rapidly increasing. However, when it comes to religious heritage, the mere sale of a spot through advertising and the visual consumption of its beauty by visitors is a questionable strategy. Rather, we need a deeper understanding and sense of place - including tourism ethics and sustainable development concepts. This study has selected two outstanding religious sites as case studies: the Ise Grand Shrine in Japan and the Stift Klosterneuburg monastery in Austria. By conducting and recording interviews with leading staff and associated stakeholders, the author obtained considerable insights into current affairs regarding tourism at religious spots in diverse cultural environments. Results so far show that both sites are still preserving their religious tradition while increasingly opening up to (international) tourists as well. Similarity exists in the welcoming of visitors and consideration of their religious affinities. Differences exist regarding the geographical choice of location of religious sites and the nature of certain religious customs and rules. Further research is needed to examine how tourists can deepen their spiritual understanding of the respective sites.
\end{abstract}

Keywords: religious heritage, landscape setting, meaning, tourism ethics, sustainability.

\section{INTRODUCTION}

Even in politically turbulent times, the global travel industry remains on a growth trajectory of around four percent annually [1]. In Japan in particular, tourist numbers have been steadily growing. Numbers only began to fall during the economic crisis in the wake of the Lehman Brothers bankruptcy (2009) and after the severe earthquake and nuclear accident in Fukushima (2011). However, the pattern of growth has since resumed. In 2015, tourist numbers in Japan almost reached the 20 million mark. In 2016, 24 million foreign tourists visited Japan (Fig. 1, ongoing trend for 2017).

Given this development, it is no surprise that the increasing number of foreign tourists in Japan and its economic benefits are highly appreciated by the Japanese government. In response to this trend, and in view of the 2020 Tokyo Olympic Games, efforts are now being made to improve the service and hospitality sectors, especially with regard to English language proficiency. However, when it comes to cultural heritage, and in particular religious heritage, the mere "selling" of a spot to tourists through advertising and the "consumption" of its beauty by visitors taking snapshots is a questionable strategy. This problem constitutes the starting point for the present study.

Outstanding spots, such as ancient Shinto shrines and temples in Japan or Christian churches and monasteries in Europe, rely on deep religious culture and tradition. In order to allow visitors to truly appreciate such spots, we have to offer reasonable guidance towards a new "sense of place" - including research on appropriate tourism ethics and codes of behaviour.

So far, tourism ethics is a rather general declaration of understanding, aiming at "mutual understanding and respect between peoples and societies" [3]. Its main focus is upon the sustainable usage of environmental resources, such as eco-tourism, and on the protection of social minorities of tourist destinations. 


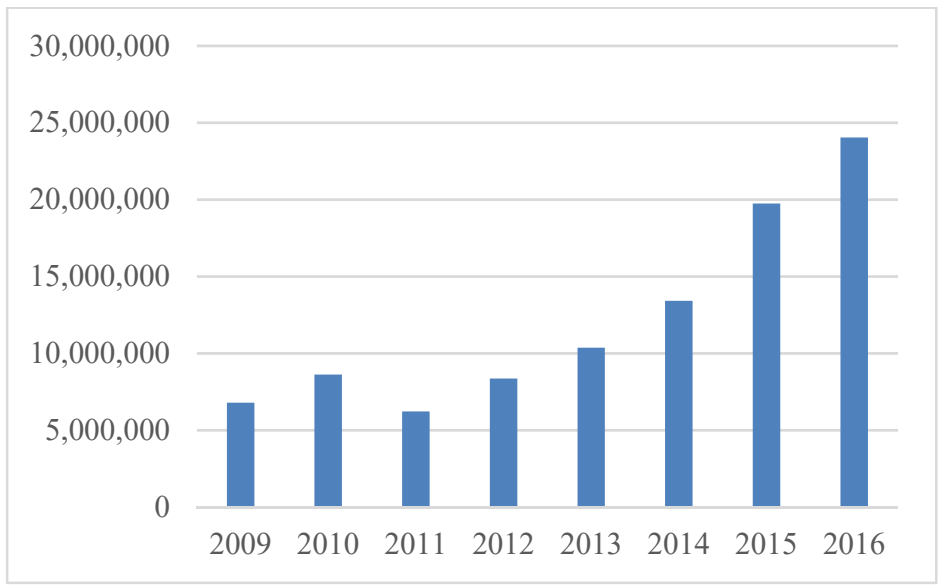

Figure 1: Foreign tourists visiting Japan. (Source: JNTO statistics [2], graph created by author.)

However, there are only a few studies dealing with tourism ethics related to sacred sites. For instance, in his latest paper about tourism ethics, Hara discusses various works dealing with tourism ethics in different countries. This essay serves as an excellent analysis, but does not explicitly focus on sacred sites [4]. Raij and Griffin's Religious Tourism and Pilgrimage Management: An International Perspective provides deep insights into pilgrimage tourism worldwide and motivations of tourists visiting sacred sites [5]. However, in practical terms, we might still ask, what are the major features that make a site sacred and that make tourists feel a special sense of place? Given an increasing number of visitors to such places, there is an urgent need for further research.

\section{RESEARCH METHOD AND CASE STUDY SITES}

\subsection{Research questions and purpose}

The majority of tourists visit religious spots and heritage sites with little prior information. This applies in particular to foreign visitors, whose experience of their holiday destination is often for the first time.

For example, Western tourists coming to Japan usually have no knowledge of Shinto, such as the meaning of a shrine building complex, its architecture, deities, religious elements, spatial design and its relationship to the environment. Nowadays this is even true for many Japanese people. In addition, tourists from overseas have no knowledge of ritual conduct and how to pray when visiting such a site.

The same can be said about Japanese tourists visiting a European church or monastery. They usually don't know the religious context and ritual conduct, and some may even hesitate to join a church service or prayer due to a feeling of psychological insecurity.

For this reason, the purpose of this study is to clarify:

1. What makes a religious site sacred, and what is necessary to keep it sacred? In this context, what are the differences between a Japanese shrine and a Christian monastery?

2. How do tourists visit such a site, what do they do and how do they behave?

3. If necessary, what could be done to improve the tourism ethics of such religious spots? 


\subsection{Case study site selection}

For this research, the author has selected two major religious spots as case study sites. The following characteristics were decisive for their selection:

1. an outstanding landscape setting;

2. a significant and continuous long history; and

3. an active religious life.

These selection criteria are briefly explained as follows:

1. Important sacred sites around the world have never been built in arbitrary locations. This is particularly true for ancient Japanese temples and shrines [6]. In the majority of cases, the landscape setting is closely linked to the religious or secular purpose of a local foundation. This should be taken into account, especially if a "sense of place" is considered to be integral to a new ethics of tourism.

2. A significant and continuous long history is a prerequisite for the national celebrity and popularity of the place. Only then it is possible to compare culturally different religious sites across continents and their potential role for heritage tourism.

3. When it comes to tourism ethics related to major religious sites, an active religious life is required to be able to compare corresponding case study sites. In Europe, for instance, there exist former monasteries that are impressive heritage sites, such as "Kloster Eberbach" on the German River Rhine [7]. However, for this paper, we need places that are not only historical, but where priests or monks are still active in their religious tradition and where people still come to pray.

The first case study site selected in accordance with these criteria is the Ise Grand Shrine in Mie Prefecture, Japan. Ise Shrine has been a pilgrimage and tourist destination for Japanese people since ancient times. However, in the wake of the G7 Ise-Shima Summit in May 2016, this outstanding Shinto shrine has been broadcast prominently in the international media. As a result, it has become more famous overseas, and has recently attracted increasing numbers of foreign tourists.

The second case study site is the monastery Stift Klosterneuburg near Vienna, Austria. Stift Klosterneuburg, like Ise in Japan, is an ancient religious pilgrimage site of national importance which also attracts many tourists. In addition, as a case study within a more rural setting, I chose another famous monastery, Stift Göttweig near Krems, which is also located in Austria.

\subsection{Research method and data collection}

In order to gain first-hand information, data were collected as follows:

1. site inspections and personal observations;

2. in-depth conversations in the form of semi-structured interviews with experts.

By conducting interviews with leading staff of these institutions, as well as relevant authorities and stakeholders, the author was able to produce valuable, original research data.

Site inspections to Ise included:

- Sengu-kan Museum - this museum explains the background of Ise Shrine Reconstruction Rituals every 20 years. 
- Ise Outer Shrine, (Geku) - one of the two major shrines of Ise (the enshrined god Toyo'uke-no-Ömikami is a patron deity of agriculture and business).

- Ise Inner Shrine (Naiku) - tour through the shrine precinct, participation in formal worship (this is the other major sacred spot; the enshrined god Amaterasu-Ōmi-kami is the sun goddess and main god of Shinto /the Imperial Household).

- Kongo-sho-ji Temple - a Buddhist temple at the top of nearby Asama-yama mountain, guardian temple for the Ise Shrine that most worshipers visited after their Ise-Jing $\bar{u}-$ shrine pilgrimage in the Edo period.

- Meoto-iwa at the Hutami-ga-ura Pacific Ocean coast - shrine and sacred rocks on the seashore; important spot where many worshipers purified body and mind during the Edo period (1603-1868), by taking a bath in the sea before worshipping at Ise.

Interviews in Ise included:

- Ise Furuichi Sangu-kaido Museum, Director Mr. Seko Tomiyasu (historical significance of the Ise pilgrimage).

- Akafuku Co. Ltd., Chairman Mr. Noriyasu Hamada (manufacturer of traditional Japanese sweets (wagashi) and developer of monzemachi districts for tourism).

- Ise Grand Shrine (Jingū), Mr. Satoru Otoba, public relations division (the meaning of Jing $\bar{u}$ and its landscape setting; stance towards visitors and tourists).

- Ise Chamber of Commerce, Mr. Fukuda Tsuyoshi, Deputy Manager of Planning Business Division (tourism promotion in Ise with regard to Jing $\bar{u}$ ).

- Kōgakkan University, Ise, Professor Christopher Mayo (history), Professor Taura Masanori (city planning), and Professor Sakurai Haruo (religion).

- Maruoka Sōda Yūtei, the last remaining onshi House, Mr. Maruoka, Masayuki (onshi were both Shinto priests and tourist guides for thousands of pilgrims to Ise during the Edo era. Out of 400 onshi residences at that time, only one is left today).

- Ise City Tourist Association, Mr. Nishimura Junichi (about Ise City's vision for tourism centred around Jing $\bar{u}$ ).

- Ise City Office, Mr. Suzaki (about problems related to Ise tourism and approaches being adopted by the city).

- $\quad$ Forest of the Ise Grand Shrine (Isejingū-rin), Mr. Okada, Jingū forest manager (information on the Jing $\bar{u}$ forest inside the precinct and surrounding Ise Jing $\bar{u}$, its role and management).

- Mie Prefectural Government Office, Mr Kanō Akio, Tourism Policy Division (discussing the tourism policy of Mie Prefecture).

\subsubsection{Case study 1, Ise Grand Shrine, Ise, Japan}

As can be seen from the listings above, the author carefully inspected all relevant places in Ise, including the two main shrine sites of Jingū, called Naiku ('Inner Shrine') and Geku ('Outer Shrine'), and related spots.

Furthermore, with regard to interviews with experts, I met with various key persons, including shrine staff and leading representatives of local administration as well as with professors of nearby Kōgakkan University.

\subsubsection{Case study 2, Stift Klosterneuburg near Vienna, Austria}

The author visited Vienna and its surroundings in August 2017. I inspected the Vienna city centre, the River Danube and the Wachau area, as well as the main case study site Stift Klosterneuburg monastery. 
As in Ise, in Austria, too, I conducted interviews with various key persons, such as the director of the "Culture, Tourism \& Marketing" Division of Stift Klosterneuburg, and the managing director of its outstanding wine estate. I further met with the "Strategy, Innovation \& Destination Management" Division of "Niederösterreich-Werbung GmbH", a semi-state organization for the promotion of tourism (see listings below). Results so far are introduced in the next section (see: 3 Preliminary results).

Site inspections to Vienna included:

- Vienna historic city centre - to gain a deeper understanding of the history of Vienna \& Austria.

- The River Danube and the Wachau rural district - the River Danube is a symbol for Austria, and the Stift Klosterneuburg monastery, the main case study site, is built directly next to it (the Wachau area is a World Heritage Site, with further outstanding monasteries, such as Stift Melk and Stift Göttweig).

- $\quad$ Stift Klosterneuburg Monastery - case study site, guided by co-director Mr. Matthias Hofmeister-Kiss and the head of vinery, Dr. Wolfgang Hamm (understanding of the culture, religious tradition and history of the site).

- $\quad$ Stift Göttweig Monastery - a famous rural Benedictine monastery on a top of a hill next to the River Danube (guided by prior Mr. Maximillian through the monastery complex).

Interviews in Austria included:

- $\quad$ Technical University Vienna, Dr. Meinhard Breiling - Dr. Breiling is a cross-cultural expert of Japan and Europe (interviews about tourism visions related to sacred spots in Austria and Japan).

- $\quad$ Augustinian monastery Stift Klosterneuburg, Mr. Gottfried Fragner - Director of the "Culture, Tourism \& Marketing” Division (discussion about history, tourism ethics and practice in the abbey).

- Augustinian monastery Stift Klosterneuburg, Dr. Wolfgang Hamm - managing Director of the Wine Estate (about the significance of wine production).

- Augustinian monastery Stift Klosterneuburg, Reverend Mag. Anton Höslinger (the abbey as a sacred spot and clerical view on tourism activities).

- Knollconsult GmbH (environmental planning office), Mr. Jochen Schmid (pilgrimage tourism).

- Klösterreich e.V. and monastery Stift Göttweig, Mr. Hermann Paschinger (Klösterreich) with Ms Eveline Gruber, Director Tourism \& Culture (Göttweig) "Klösterreich" is an association for the promotion of cultural tourism activities of monasteries.

- Monastery Stift Göttweig, Prior P. Mag. Maximilian Krenn (on history, social, cultural and spiritual roles of the Göttweig monastery, and cultural tourism).

- $\quad$ museums management Niederösterreich, Ms Mag. Ulrike Vitovec (on how they made a vision with stakeholders, halls, museums, cultural events, festivals, etc. and succeeded in revitalizing the region of Niederösterreich).

- Niederösterreich-Werbung GmbH, Mr. Stefan Bauer, Strategy, Innovation \& Destination Management (on tourism promotion, innovation and the role of religious tourism in Lower Austria).

\section{PRELIMINARY RESULTS}

As shown in the listings above, in total, 20 interviews were conducted and recorded, with an average duration of more than one hour per interview. However, more time is needed to 
complete the transcription, translation and interpretation. Preliminary results so far, and in particular for this paper, are based on the following data:

Altogether, from among these 20 recordings, six meaningful interviews have been selected and transcribed: three for each of the two destinations, the Ise Shrine in Japan and the Monastery Stift Klosterneuburg in Austria. Two criteria played a role in the selection. Firstly, they should cover important institutions and different aspects of this research. Secondly, interviews with similar institutions both in Japan and Austria have been selected, in order to make results comparable and interpretable.

Key messages from these interviews concerning the most important research questions are summarized below for each case study. Finally, a short comparative discussion is given.

\subsection{The Ise Grand Shrine, Japan}

\subsubsection{Landscape setting}

The Ise Grand Shrine is located in central Japan, south of Nagoya, in Mie Prefecture, Ise City, near the Pacific Ocean.

For the Ise Grand Shrine, the landscape setting is considered to be most important. Its background lies in the close relationship of many Shinto shrines with the natural environment. In the past, many shrines were set up amidst beautiful scenery, within forests or next to mountains and streams, and Ise is no exception. There are two reasons for this:

The first reason is a practical one. Many shrines were built at spring sources which provide access to drinking water. The existence of the shrine thereby ensured the preservation of the water source.

The second reason is a religious one. There is no simple definition of the Shinto belief or tradition, but in a nutshell, the following may be said: Shinto is based on three pillars: first, Shinto related to local clans (ancestral worship), second, Shinto related to the Japanese Imperial Household (emperor worship), and third, Shinto related to natural objects, such as old trees, rocks, springs, rivers, and agriculture (nature worship) [8], [9].

Table 1: Expert interviews analysed for this paper. (Source: Author.)

\begin{tabular}{|c|c|c|}
\hline $\begin{array}{l}\text { Int. } \\
\text { No. }\end{array}$ & Institution/person/location/interview duration (time) & $\begin{array}{l}\text { Institutional } \\
\text { category }\end{array}$ \\
\hline 1 & $\begin{array}{l}\text { Mr. Satoru Otoba, assistant manager of the Public Relations Division } \\
\text { of Jingu Administration Office, Ise (Ise Grand Shrine, Japan) } \\
(01: 14: 22)\end{array}$ & \multirow{2}{*}{$\begin{array}{l}\text { Public relations, } \\
\text { culture, \& visitor } \\
\text { management (of } \\
\text { the religious site) }\end{array}$} \\
\hline 2 & $\begin{array}{l}\text { Mr. Gottfried Fragner, director of the Public Relations and Culture } \\
\text { Division, Klosterneuburg City (Stift Klosterneuburg, Austria) } \\
(00: 54: 57)\end{array}$ & \\
\hline 3 & $\begin{array}{l}\text { Mr. Akio Kano, manager, Prefectural Tourism Policy Division, } \\
\text { Tourism Bureau, Tsu City (Mie Prefecture, Japan) (01:11:40) }\end{array}$ & \multirow{2}{*}{$\begin{array}{l}\text { Regional tourism } \\
\text { policy institution } \\
\text { (state / prefectural } \\
\text { level) }\end{array}$} \\
\hline 4 & $\begin{array}{l}\text { Mr. Stefan Bauer, general manager, Niederösterreich-Werbung GmbH, } \\
\text { St. Pölten, tourism policy agency of the federal state Lower Austria } \\
(00: 46: 56)\end{array}$ & \\
\hline 5 & $\begin{array}{l}\text { Prof. Dr. Masanori Taura, Prof. Dr. Haruo Sakurai, Kōgakkan } \\
\text { University, Ise City, Faculty of Letters (Department of } \\
\text { History/Religion) }(01: 23: 26)\end{array}$ & \multirow{2}{*}{$\begin{array}{l}\text { Academic } \\
\text { professionals for } \\
\text { culture, history } \\
\text { and planning }\end{array}$} \\
\hline 6 & $\begin{array}{l}\text { Dr. Meinhard Breiling, Technical University Wien, Vienna, Center of } \\
\text { Interfaculty Cooperation: "Technology. Tourism. Landscape" } \\
(01: 24: 19)\end{array}$ & \\
\hline
\end{tabular}




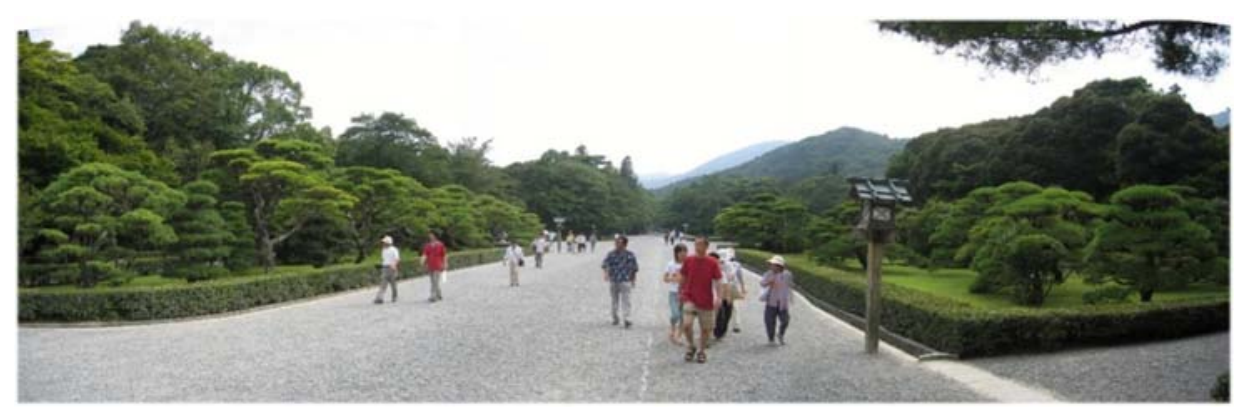

Figure 2: Access road within the Ise Grand Shrine, exposing a splendid scenic view. Lawn and trimmed pine trees were added during the Meiji Period. (Picture taken by Author.)

The Ise Grand Shrine or Jingū is closely related to the Imperial Household (compare 3.2.2, but also maintains a deep respect for nature. As can be seen in the picture below, the shrine precinct is set within a large, beautiful forest (Fig. 2).

The importance of the natural environment to Ise Jingū was apparent in interview No. 1 with Mr. Satoru Otoba from the shrine administration office, who returned repeatedly to this topic.

In the first part of the interview ( 00:05:42), Mr. Otoba underlines the importance of clean water for human life. In Ise, the shrine was purposely established next to the Isuzu River.

This clean stream represents purification, which is very important in Shinto belief, and also benefits the cultivation of rice paddy fields. He mentions that in the ancient chronicle of Japan, the Nihonshoki, it is written that the daughter of the 11th Emperor Suinin, Yamatohime-no-Mikoto, received divine guidance from the main deity, Amaterasu-Ōmikami, that Ise is the "beautiful country" ("umashi-kuni") where she finally wants to be enshrined (the shrine was moved to the present site about 1,300 years ago). Thus, the lush forests and clean streams around Ise Jingū provide one reason for its site selection and landscape setting.

Another reason is that Ise is also facing the sea of Ise Bay (Ise-wan). In practical terms, this means access to fresh fish and seafood. In religious terms, however, one can assume that facing the sea of Ise Bay was considered a sacred location, as it thus faces out eastward towards the sunrise, and Amaterasu is considered to be the sun goddess that gives life. This possibility is mentioned by Okada Seishi in his study Kodai Ōken no Saishi to Shinwa (The Rituals and Myths of Kingship in Ancient Times) [10].

Finally, Mr. Otoba explains that Ise's access to the Ise Bay meant an important strategic location for the Yamato Imperial Court (today's Nara basin). By connecting Yamato and Ise, the court could send ships to the Eastern provinces of Japan, which were not yet subject to their rule. Ise's strategic location as a gateway towards Eastern Japan is also mentioned by Naoki Kōjirō in his book Ise Jingū to Kodai no Kamigami (Ise Jingū and the Gods of Antiquity) [11].

In addition, in interview No. 5, when asked about the relationship between the Ise Shrine and surrounding towns, Professor Taura from Kōgakkan University makes clear that the shrine existed first-hand (00:05:54 ). Originally, urban development started next to the two major shrine complexes (o-yashiro), the Inner Shrine (Naiku) and Outer Shrine (Geku) respectively, which grew into two different towns named "Uji" and "Yamada". Such 
developments are known in Japanese as monzenmachi ("a town in front of the main gate of a temple or shrine"). In the modern era, these two towns were integrated into one city called "Ise".

To sum up, these indicators suggest that the Ise Shrine's setting was most likely determined on account of the outstanding surrounding scenery, its proximity to the Pacific Ocean facing the rising sun, and its advantageous strategic location for the Yamato Imperial Court.

\subsubsection{Religious tradition and significance}

Throughout its history, the Ise Grand Shrine or Jing $\bar{u}$, as the main Shinto shrine of the Imperial Household, has always played a major role as a very significant religious spot. In Japan, it is generally considered that the sun goddess Amaterasu-Ōmikami is the ancestor of the Japanese Emperor's family line. In this context, before the end of World War II the Japanese Emperor was even regarded as a living god. However, as a consequence of the misuse of Shinto to nationalistic ends, following the end of the war the Emperor was obliged to declare that he was not a god-like being. He is nonetheless still regarded as the highest Shinto priest even today.

The religious significance of Jing $\bar{u}$ is also shown by the fact that pilgrimage to Ise began as early as the Nara Period (710-794 AD). In interview No. 1, Mr. Otoba explains that in ancient times, the general public could not easily worship at Ise Shrine. Direct access to the sacred shrine grounds was limited to "imperial messengers" (choku-shi) and members of the Imperial Court (chö-tei) (00:20:15 ).

From the Kamakura Period (1185-1333), other social groups gradually gained access. These included high class Buddhist priests of big temples such as Todai-ji in Nara, since at that time Buddhism and Shintoism were closely connected.

From the Edo Period (1603-1868), ordinary people could visit Ise. Their visit was organized by special shrine priests called onshi, who functioned as a tourism agency between the gods (kami) and worshippers (sühai-sha). It is remarkable that people from all over Japan embarked upon such long-distance treks of hundreds of kilometres in order to pray in Ise to Amaterasu-Ömikami. Mr. Otoba considers this to be the first wave of pre-modern tourism in Japan.

In addition, with regard to Ise Jing $\bar{u}$ 's religious significance among Japanese people today, Mr. Otoba notices a change in people's visitor patterns and purpose of visit (00:44:30 ). While in the past, people visited the shrine mostly for New Year prayers (hatsu-mōde), recently, younger people come throughout the year. In addition, rather than believing deeply in the Shinto gods (kami), now most visitors enjoy visiting Ise Jing $\bar{u}$ as a healing space (iyashi-no-kükan) or spiritual home (kokoro-no-yori-dokoro). They find emotional and spiritual relief in a pure, natural setting, considering Ise Jing ū mainly as a "power-spot". Mr. Otoba says that the shrine is not concerned about this trend. Once people visit, the shrine may teach them a deeper understanding of the spot and its religious significance.

\subsubsection{Preservation and sustainability aspects}

Today, the Ise Grand Shrine is engaged actively in the preservation of its precincts and sacred shrine forests (chinju-no-mori), and in the sustainability of its unique building complexes (see below for details).

However, as Mr. Otoba explains, this has not always been the case. From the late Edo Period over-exploitation of timber from the forests surrounding the shrine gave rise to an environmental crisis in Ise. The more people came to visit Ise, the more natural resources were needed, such as firewood, charcoal and lumber, which led to deforestation and 
degradation of the wooded mountain landscape. As a result, by the Meiji Era (1869-1911), the Kamiji-yama mountain seen from the Uji-bashi Bridge looked like a bald hill, as almost all trees had been cut down ( 00:35:05).

As a result, during the Taishō Era (1912-1926) in 1918, when $350 \mathrm{~mm}$ of rain fell per hour, a major flood struck the Ise Jing $\bar{u}$ shrine area. The Isuzu River burst its banks, and more than 100 landslides occurred along the river. At that time all the houses in front of the shrine precinct (monzen-machi) were flooded.

To deal with this challenge, Ise Jing $\bar{u}$ decided to set up a forest management plan. It was developed by leading Japanese experts, Dr. Seiroku Honda (1866-1952) of Tokyo Imperial University (today's University of Tokyo), and Dr. Zentarō Kawase (1862-1932) of the Imperial Forestry Bureau. Their plan proposes the following three measures:

1. To reconsider the rich "guardian forest" of ancient times (chinju-no-mori)

2. To foster "recharging of groundwater" (kanyō) so that the river will not flood again, no matter how much rain falls. If many trees are growing in the forest, the forest will work like a sponge and release the water only little by little.

3. To provide all the materials, especially Japanese cypress (hinoki) for the "Jingu Shikinen-seng $\bar{u}$ ritual" (reconstruction of the complete shrine complex every 20 years from Ise Jingū's own forests which is called "Misoma-yama" (= the saint hinoki lumber forest).

In addition, it was decided to cultivate mixed forests combining broad-leaved and deciduous trees on the slopes near the Jing $\bar{u}$, which can be seen from Uji-bashi Bridge. The evergreen conifer trees, mainly Japanese cypress, were planted on the mountain behind.

As a result of this planning, the Jing $\bar{u}$ was gradually surrounded once more by mixed natural forest. No matter what kind of typhoon came afterwards, the Isuzu River did not flood again. Today, Ise manages a large forest area inside and outside the shrine precinct. This forest is a combination of planted forest and natural forest.

Another unique aspect of Ise Jingū's environmental management is the above-mentioned Jingū Shikinen-sengū ritual. Every 20 years, the entire shrine complex and ritual and artistic artefacts are reconstructed. In Europe, where preservation means preserving the original historical building stock to the greatest extent possible, it is difficult to imagine that a complete reconstruction every 20 years could be described as sustainable preservation. However, in the hot and humid Japanese climate, with shrine buildings completely made from wood, the European method of preservation is very difficult to achieve. Rather, the perfect reconstruction of the shrine buildings every 20 years ensures that essential carpentry skills are passed on to the next generation whilst the original shape of the shrine complex is preserved. Yet such regular, costly and meticulous reconstruction is rare even within Japan.

\subsubsection{Tourism policy, rules and attitudes towards tourists}

While Ise experienced a constant flow of visitors in pre-modern times, after World War II, less people travelled there. Among other reasons, one factor has been the change of lifestyle in the form of motorization - in the past, all people walked to the Jing $\bar{u}$ through the main street of the monzenmachi town. However, from around 40 years ago, pilgrims began increasingly to arrive by car or bus. Akafuku Ltd., originally a Japanese sweet company, became aware of this situation, and, in cooperation with Ise City and Mie Prefecture, they redesigned the main street next to the Inner Shrine, called Oharai-machi, in the style of the original historical streetscape. In recent years, tourist numbers have increased, and people enjoy strolling through this street again. 


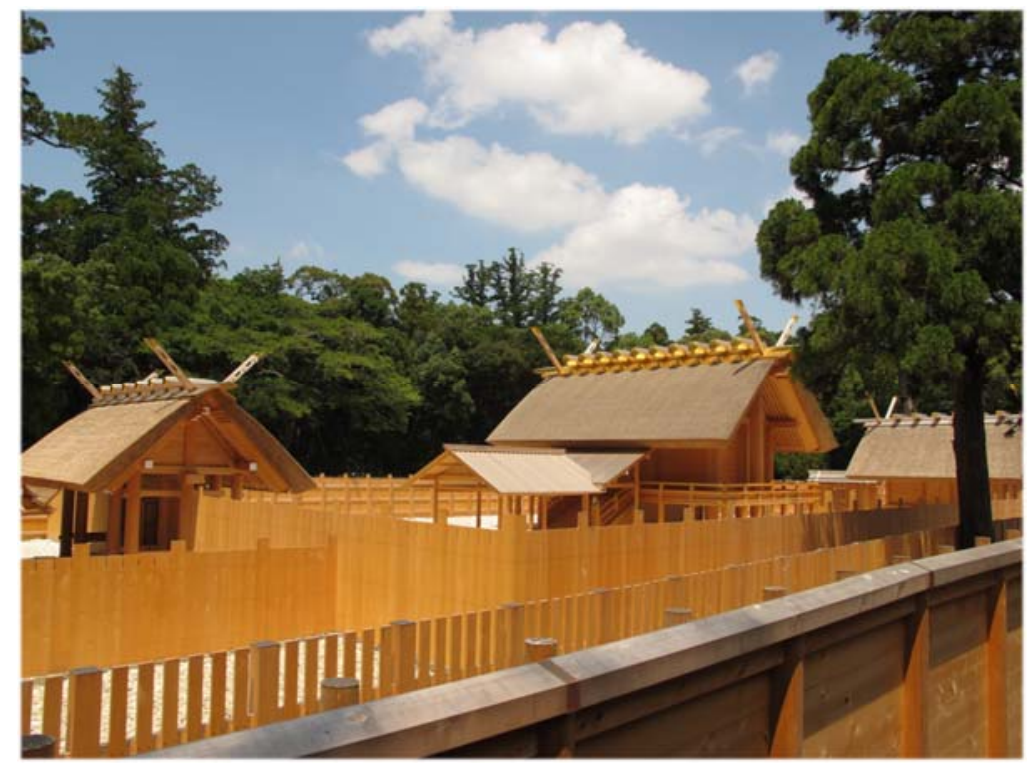

Figure 3: The main building complex of the Ise Grand Shrine after its latest reconstruction in 2013; it will serve until 2033. (Picture taken by (C) the Ise Jingū administration office.)

An important point in order to establish a modern tourist policy, mentioned by both $\mathrm{Mr}$. Otoba and Professor Taura during their interviews, is that the administrations of Mie Prefecture and Ise City have recently improved their relationship with Ise Jing $\bar{u}$. Twenty years ago, the local administration and shrines did not make much contact with each other due to the separation between politics and religion after World War II (sei-kyo-mondai). But it seems that this fence has been removed now. Tourist guides from the city, some even with English language skills, are now educated by the shrine about the policy and rules within the shrine precincts.

What behaviour is expected from tourists visiting the shrine precinct? Basically, shrine visits and personal prayer are free of charge, and visitors from all backgrounds and religions are welcome. Upon payment of a fee, a visitor can even receive a formal Shinto ceremony. In this case, formal clothing is required. Eating, drinking, and smoking are not allowed in the precinct.

As manner and purification are vital to Shinto, it is appreciated when guests bow at the torii gates (marking a sacred space) and ritually clean their hands and mouth at the water basins (temizuya) at the entrance to the shrine. Another rule, that sometimes is not understood by foreign visitors, is the fact that it is forbidden to take pictures at the site for prayer and of the main sanctuary (in Shinto, it is an old tradition that gods or kami are and should remain invisible, and any attempt to "catch" them via taking pictures is not welcome).

While bad behaviour by tourists at the shrine seems to be rare, Mr. Otoba from the shrine office and Mr. Kano from the Prefectural Tourism Policy Division both said that numbers of foreign tourists are low. This related to the fact that Ise is regarded as being far away from Tokyo or Osaka, off the beaten track, even though in practice train connections are not too onerous. 


\subsection{Stift Klosterneuburg, Austria}

\subsubsection{Landscape setting}

The Augustinian monastery Stift Klosterneuburg is located in Austria, near the suburbs of Vienna.

As in the case of Ise, the landscape setting is very important for the monastery. However, a distinct difference between Christian belief and Japanese Shinto tradition is that the landscape setting of Stift Klosterneuburg was not selected in order to connect with or even worship nature itself. Christian worship happens inside a church or chapel, not outside in the open space like Shinto.

In interview No. 2, Mr. Fragner, director of the Public Relations and Culture Division of Stift Klosterneuburg, underlines the strategic location of Klosterneuburg as the main reason for its choice of location ( 00:15:03). When asked if the monastery's landscape setting in the countryside is related to a sacred place, he answered as follows: "I don't think so, no. Here in Klosterneuburg it was a Roman settlement, a large fortification, until about $500 \mathrm{AD}$, exactly in this place, exactly where we are now sitting, there are still Roman excavations. It was a purely a strategic choice by (the local lord and Margrave) Leopold III. of the Babenberger dynasty, that they settled down here. In the past, the Danube River flowed directly past the monastery, which meant you could use the river directly. And the Danube made a small bend here. From (the top of this hill) here you could see in all directions across the region".

Mr. Fragner further mentioned that self-sufficiency, self-production of all goods needed in daily life, was extremely important for all monasteries. A main factor to ensure stable selfsufficiency was real property and agriculture. That is why the monastery is surrounded by crops and orchards, that is to say, cultural landscape. In the case of Klosterneuburg, wine production has been an important economic factor from the beginning.

Moreover, Klosterneuburg has a special status because it was always a particularly rich monastery, thanks to generous land donations from lord Leopold in 1114 AD (00:03:30).

In the deed of foundation, it is fixed that when a plot of land is sold, another plot of the same quality has to be bought again. Thanks to this generous arrangement from the very beginnings, the monastery has been able to finance pastoral activities and spiritual counselling in all of its 28 regional parishes and overseas branches.

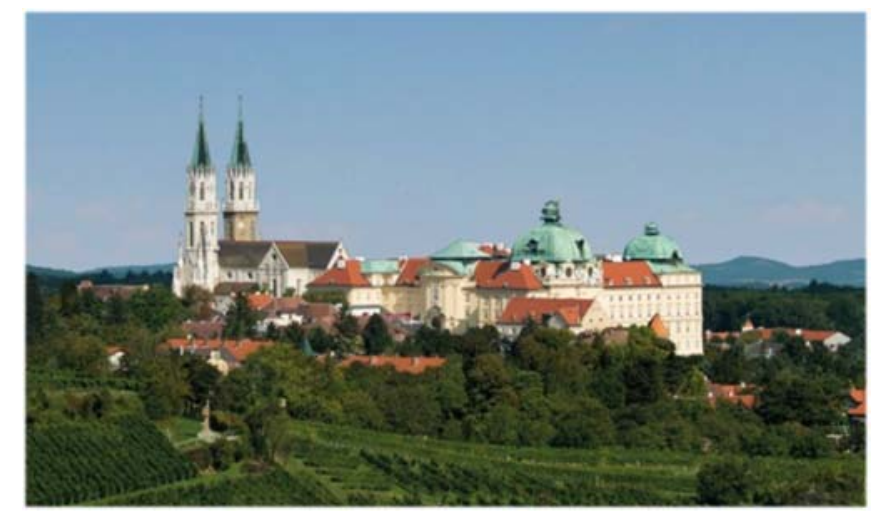

Figure 4: The Augustinian Monastery Stift Klosterneuburg surrounded by its own wine fields within a cultural landscape. (Picture from (C) Stift Klosterneuburg, Michael Zechany.) 
In addition, the monastery later became the burial place of lord Leopold III., who was later canonised as Saint Leopold, the patron of the state of Austria. It has thus always played an extremely important role for the monarchy, especially later for the Habsburg family.

To sum up, the landscape setting of Stift Klosterneuburg reflects a strategic decision by the local lord and the church to secure the power. It was also well suited to the development of the state and region, including agricultural land-use and cultivation. The monastery with its own agriculture and viticulture was also an employer and breadwinner for the local population. This point was stressed by Dr. Breiling (interview No. 6). From this it is clear that the monastery, although spiritually a centre of the faith, also fulfilled worldly purposes from the very beginning.

\subsubsection{Religious tradition and significance}

Stift Klosterneuburg is one of the largest Christian Catholic monasteries in Austria and its original benefactor Saint Leopold is also the patron of Austria. In this sense, as with Ise Jing $\bar{u}$ in Japan, it has nationwide importance. It has also been a pilgrimage destination since the Middle Ages, since lord Leopold was regarded as a saint soon after his death. It is said that Leopold served his own people with great compassion and wisdom, took care of children, and never looked down on common residents. Unlike most rulers of the time, he also avoided going to war with other kingdoms. This brought him great sympathy and recognition among the population and is the reason why he became a Saint [9].

Asked about what is considered most sacred, Mr. Fragner empathized that the monastery has been a centre of belief since ancient times, but also of study. It has the largest private library in Austria, with more than 300,000 books, and a collection of 1,200 original handwritten manuscripts from the Middle Ages. In addition, he stressed that the location itself is not considered sacred ( 00:09:34). However, within the building complex of the monastery, there are three sacred spots: the Leopold Chapel, where St. Leopold is buried, the fountain house, where each monk is prepared for burial at the end of life when he dies, and the collegiate church, where the services take place.

\subsubsection{Preservation and sustainability aspects}

In economic terms, as an employer in the region, Stift Klosterneuburg Monastery can be considered sustainable, as it offers stable and safe workplaces. However, in ecological terms, sustainability is even more pertinent. Its more than 100 ha of vine fields have been cultivated over the past 900 years by the monastery itself, today under climate-neutral production and integrated cultivation, using only very few chemical fertilizers and pesticides. Its 240 ha of agricultural crops are even managed organically. Details of these practices were explained to the author by Dr. Wolfgang Hamm, leading director of the vinery, and are also mentioned by Redtenbacher [12].

In terms of the physical preservation of the site and its buildings, the proper preservation of the whole the building complex, treasures, ancient books and the collegiate church is taken very seriously. Their outstandingly good condition was clearly apparent to me during my tour of the monastery and church. No effort and costs are spared. In 2014, there was a general restoration and clean-up of the buildings, which consumed a high double-digit million-sum of Euros, and to a large extent was paid by the monastery itself, with additional federal state financial support.

\subsubsection{Tourism policy, rules and attitudes towards tourists}

In Klosterneuburg, tourists from all over the world and of all faiths are welcome. In fact, more than $60 \%$ of the visitors are Austrians. The newly designed homepage is available in English and various other languages, including Chinese and Japanese. 
Entrance fees are levied for tourist visits to see the historical monastery buildings, vinery, treasury, or special exhibitions. However, religious services are performed free of charge, even for Protestants or followers of other religions, if they wish.

Recent success in increasing visitor numbers, currently 100,000 people per year, should not, however, run out of control. Openness does not mean mass tourism. During the interview, Mr. Fragner explains that high quality cultural tourism remains a main goal. For instance, a group of visitors should be able to visit the church on their own, without being disturbed by the next group coming in. Stift Klosterneuburg also offers cultural and artistic workshops for children and families to enable them to experience culture and handicraft first hand.

With regard to rules for tourists, tourists are allowed to take pictures in the church and monastery, except during church services. Furthermore, there is no longer any obligation to wear formal clothes. Mr. Fragner reports that bad behaviour, such as eating ice cream in the church or treasury, or entering the church in a drunken state, remains very exceptional. Overall, people from all countries behave well and do not even take selfies with long sticks.

In addition, in interview No. 4, Mr. Stefan Bauer, general manager of the Niederösterreich-Werbung GmbH, St. Pölten, a tourism policy agency of the federal state Lower Austria, underlines the general significance of pilgrimage tourism and abbeys in the region. There are various pilgrimage destinations, such as Maria Zell, and tourism products promoted as Genussregion (pleasure region) include many things that monasteries can offer, e.g. the pleasure of locally produced wine and fruits, the pleasure of cultural assets, and the pleasure of enjoying a beautiful pastoral setting in the countryside. Sustainable and innovative tourism for various age groups is en vogue.

\section{DISCUSSION AND CONCLUSION}

This essay does not claim to answer all the questions outlined at the beginning comprehensively. Nonetheless what observations and conclusions are possible for now?

Regarding the first research question, "What makes a religious site sacred, and what is necessary to keep it sacred?" interview partners from both institutions underlined that they are first of all a place of faith, and subsequently a place with a long history and cultural treasures to be enjoyed. That means, for instance, despite the opening up to international guests, and liberalization of regulations such as dress codes, etc., visitors are expected to behave appropriately. Surprisingly, most visitors do so, maybe through gut instinct, even if they do not know much about the belief of their foreign destination (or even their own native religion). Despite this fundamental commonality, there are also differences.

For the Grand Shrine of Ise, "being sacred and keeping the shrine grounds sacred" means, above all, preserving purity, through ceremonies and rules, both in a physical sense, hence purity of the natural environment and shrine buildings, and spiritually, in a metaphysical sense of the heart, the mental attitude, the respect for the invisible divine.

For the Monastery Stift Klosterneuburg, "being sacred and keeping the monastery sacred" rather means pastoral action on-site, on the ground, church services given for free and for everybody, and responsible caretaking of "mother nature" as divine creation, as they do in a sustainable and environmentally-friendly way in agriculture and preservation. Further, and in contrast with the Ise Grand Shrine, education has always been considered important in a monastery - and remains so today, as various cultural study and learning opportunities within the monastery reflect, in form of exhibitions and workshops. However, the Shinto shrine is now catching up, has a new shrine museum and offers more guides, also for foreign guests.

Regarding the second research question, "How do tourists visit such a site, what do they do and how do they behave?", it became clear that a) people instinctively behave well when 
visiting such religious sites, and b) that most people visit for various reasons, almost a combination of some religious aspirations and rather worldly desires. Whether they enjoy delicious wine in Klosterneuburg after a collegiate church visit, eat in the monastery restaurant or enjoy Japanese sweets and tea in Ise after the shrine visit ultimately makes no difference. It was interesting to note that the sacred and profane was already a "package" or "set" for pilgrimage in ancient times, in both cultures.

And yet, with regard to the third question, "What could be done to improve tourism ethics?", there is probably a difference: whereas in the past there was more physical distress outside, nowadays, the distress inside people's hearts and minds seems to be the bigger one. All interview partners confirmed this trend to the author. The search for the meaning of life is a motive of many visitors, besides the small, nice, and profane pleasures that we all like, and the author of this paper is no exception.

What the author sometimes missed during the interviews both in Ise and Klosterneuburg were thoughts about how such a quest for peace of mind may well be met in an even better way. For sure, there is no simple answer to that question, as people are all different, with individual problems and needs. However, probably more could be done to lead visitors to a deeper sense of place and spiritual experience, at least for those who are looking for such approaches. More research is necessary to provide better answers.

\section{ACKNOWLEDGEMENTS}

Research for this paper is based on donations by the Uehiro Foundation on Ethics and Education, Tokyo, Japan. The author sincerely thanks the foundation for its support.

During research in Ise, and for the transcription and translation of interviews in Japanese language, I have been wholeheartedly supported by Associate Professor Dr. Masaya IWASAKI from Kōgakkan University (Ise). Words cannot express my deep gratitude.

Further, Associate Professor Dr. Tadashi TAKENOUCHI from Tokai University and his kind wife Akiko also have been supporting me with translation and advice. Thank you so much! In addition, Dr. Alice Freeman from the University of Oxford kindly corrected the English language and gave valuable feedback on the content of this paper as well. Thank you very much, Alice! Finally, the author thanks all interview partners listened in this paper for their precious time and support.

Last but not least, many thanks to my caring wife Michiko, who again and again had to accept my absence.

\section{REFERENCES}

[1] ITB World Travel Trends Report 2016/2017. Prepared by IPK International on behalf of ITB Berlin - The World's Leading Travel Trade Show ${ }^{\circledR}$. www.itb-berlin.de/ Presse/Downloads/Publikationen/. Accessed on: 27 Dec. 2017.

[2] Japan National Tourism Organization (JNTO), Statistical Information, www.jnto.go.jp/eng/ttp/sta/index.html. Accessed on: 27 Dec. 2017.

[3] World Tourism Organization, Global Code of Ethics For Tourism, 1999. http://ethics.unwto.org/en/content/global-code-ethics-tourism. Accessed on: 27 Dec. 2017.

[4] Hara, K., A Preliminary Consideration on the Development of Tourism Ethics, Proceedings of JITR Annual Conference, 31, pp. 341-344, 2016 (in Japanese).

[5] Raij, R. \& Griffin, K. (eds), Religious Tourism and Pilgrimage Management, An International Perspective, 2nd ed., CAB International, 2015.

[6] Graphard, A.G., Flying mountains and walkers of emptiness: Towards a definition of sacred space in Japanese religions. History of Religions, 21, pp. 195-221, 1982. 
[7] Poggendorf, L., Innovative cultural tourism on the German River Rhine - Regional development and local success: How the monastery Kloster Eberbach sets new standards. Journal of Tourism Studies, 16, pp. 97-116, 2017.

[8] Naumann, N., Schintô und Volksreligion - Japanische Religiösität im historischen Kontext. Geschichte der religiösen Ideen, Bd. III/2, ed. M. Eliade, Herder Verlag: Freiburg, pp. 304-324, 1991.

[9] Sonoda, M., Shinto and the natural environment. Shinto in History: Ways of the Kami, eds J. Breen \& M. Teeuwen, University of Hawai'i Press: Honolulu, Hawai'i, pp. 3246, 2000.

[10] Okada, S., Kodai ōken no saishi to shinwa, Hanawa Shobō, 1970.

[11] Naoki, K., Ise Jingū to Kodai no Kamigami, Yoshikawa Kōbunkan, 2009.

[12] Redtenbacher, A., Wo sich Wege kreuzen - 900 Jahre Augustiner Chorherrenstift Klosterneuburg, Herder Verlag: Freiburg, 2013. 